\title{
Annual Life Cycle of Cave Bats in Northern Algeria
}

\author{
Kazimierz KOWALSKI, Jiři GAISLER, Hassiba BESSAM, \\ Cherifa ISSAAD \& Hassen KSANTINI
}

Kowalski K., Gaisler J., Bessam H., Issaad Ch. \& Ksantini H., 1986: Annual life cyrle of cave bats in northern Algeria. Acta theriol., 31, 15: 185-206 [With 1 Table, 4 Figs. \& Plate VII].

The dynamics of bat populations in caves of northern Algeria were studied between 1978 and 1983 . The 10 species represented were: $R h i-$ nolophus ferrumequinum, $R$. mehelyi, $R$. blasii, $R$. euryale, $R$. hipposideros, Myotis blythi, $M$. emarginatus, $M$. nattereri, $M$. capaccinii and Miniopterus schreibersi. Detailed reproductive data, including histological examination of reproductive organs, were obtained for $R$. mehelyi and $M$. blythi during a part of the annual cycle. All species examined except Miniopterus schreibersi reach their southern limits of distribution in Algeria. The duration of hibernation was shorter in Algeria than in Europe, but the reproductive cycle was similar in that insemination took place in autumn and fertilization in spring. Parturition occurred earlier than in European populations of the same species. Observations were made on the choice of roosts, formation of intraand interspecific associations, as well as individual and geographic variation in dates of parturition. The tendency of $M$. blythi to form harems during the mating season was noted.

[Institute of Systematic and Experimental Zoology, Polish Academy of Sciences, Slawkowska 17, 31-016 Kraków, Poland (KK), Institute of Zoology, J, E. Purkyně University, Kotlářská 2, Brno, Czechoslovakia (JG), and Faculty of Biology and Earth Sciences, University of Oran, Es Senia, Algeria (HB, ChI, HK].

2. Material and methods . . . . 186

3. Dynamics of bat populations at particular subterranean sites . . 186 3.1. Mines at Sig . . . . . . . . . . . . . . . . 186

3.2. Misserghin.$+ \quad$. . 189

3.3. Aokas . . . . . . . . . . . . . . . 191

3.4. Other caves . . . . . . . . . . . . . . . . . 192

4. Annual life cycle of particular species . . . . . . . . . . 194

4.1. Rhinolophus ferrumequinum (Schreber, 1774) . . . . . . . . 194

4.2. Rhinolophus blasii Peters, 1866 . . . . . . . . . . . 195

4.3. Rhinolophus euryale Blasius, 1853 . . . . . . . . . . 195

4.4. Rhinolophus hipposideros (Bechstein, 1800) . . . . . . . . 196

4.5. Rhinolophus mehelyi Matschie, 1901 . . . . . . . . . . 196

4.6. Myotis blythi (Tomes, 1857) . . . . . . . . . . . . 197

4.7. Myotis nattereri (Kuhl, 1818) . . . . . . . . . . . . 199

4.8. Myotis capaccinii (Bonaparte, 1837) . . . . . . . . . . . . 199

4.9. Myotis emarginatus (Geoffroy, 1806) . . . . . . . . . . . . 199

4.10. Miniopterus schreibersi (Kuhl, 1819) . . . . . . . . . 200

5. Discussion . . . . . . . . 201

References . . . . . . . . . . . . 203 


\section{INTRODUCTION}

The annual life cycle of cave bats in the temperate zone of the Northern Hemisphere, especially in Europe and North America, is well known, especially with regard to their hibernation and reproduction. General information regarding the ecology of cave bats have been presented by Kunz (1982) and Hill \& Smith (1984). McNab (1974) studied the biology of temperate-zone bats under subtropical conditions in America. However, apart from a few isolated observations, the biology of cave bats in North Africa is unstudied.

All bats occurring in northern Algeria are of Palaearctic origin, and the vast majority reach their southern limits of distribution in this region (Anciaux de Faveaux, 1976; Gaisler, 1983, 1984; Kowalski, 1979, 1984). M. schreibersi, of very wide distribution, is an exception.

The study of cave bats in northern Algeria provided the opportunity to obtain data on their hibernation from a region where winter temperatures generally are higher than in the European portion of their ranges.

\section{MATERIAL AND METHODS}

Data were collected in 1978-1983. During this period the sernior author made regular surveys of the bats at Sig and Misserghin near Oran, and sporadic observations at other localities, chiefly in Western Algeria. J. Gaisler carried out regular surveys at Aokas in Kabylia from 1981-1983, and also visited other bat roosts in that region (Fig. 1). H. Bessam studied the reproduction of $M$. blythi on the basis of the specimens collected in Misserghin Cave from March till June 1982. Ch. Issaad was occupied in studying the reproduction of $R$. mehelyi on the basis of the data from the same cave and period. H. Ksantini investigated the hibernation of bats at Sig and Misserghin and the reproductive cycle of male $M$. blythi in the $1982 / 1983$ winter. The last three studies were theses prepared under the direction of $\mathrm{K}$. Kowalski in the Institute of Biology and Science of Earth of the University at Oran. They comprised histological investigations of the reproductive organs by standard methods.

Estimates of the numbers of bats are based on visual counts of roosting bats. They are approximate, especially in the case of bats which were active or formed big clusters (Figs. 2-4).

\section{DYNAMICS OF BAT POPULATIONS AT PARTICULAR SUBTERRANEAN SITES}

\subsection{Mines at Sig}

The mines at Sig are located in the vicinity of the town of Sig $\left(35^{\circ}\right.$ $32^{\prime} \mathrm{N}, 0^{\circ} 12^{\prime} \mathrm{W}$ ) in north-western Algeria. They are abandoned diatomite mines situated about $150 \mathrm{~m}$ a.s.l. in the slopes of the Beni Chougrane 
Mts. Two mines examined are about $3 \mathrm{~km}$ apart, with a dam and a permanent water reservoir between them. The sites are surrounded by mountains stripped of woods, with single trees and thickets on them and orchards and cultivated fields not far away.

The abandoned mine galleries are horizontal or slanting down from the entrance, airy in the first sections and devoid of air circulation in the deepest parts. Complex A is a network of criss-cross galleries, their high-lying portions being partly lighted owing to their proximity to exits, while the lower parts are dark and damp in winter. Complex B consists of several tiers of generally horizontal unbranched galleries $100-200 \mathrm{~m}$ long. The two longest galleries regularly provided shelter to bats; in others bats were met rarely and in small numbers. Temperature was measured only from December 1.982 to April 1983. In

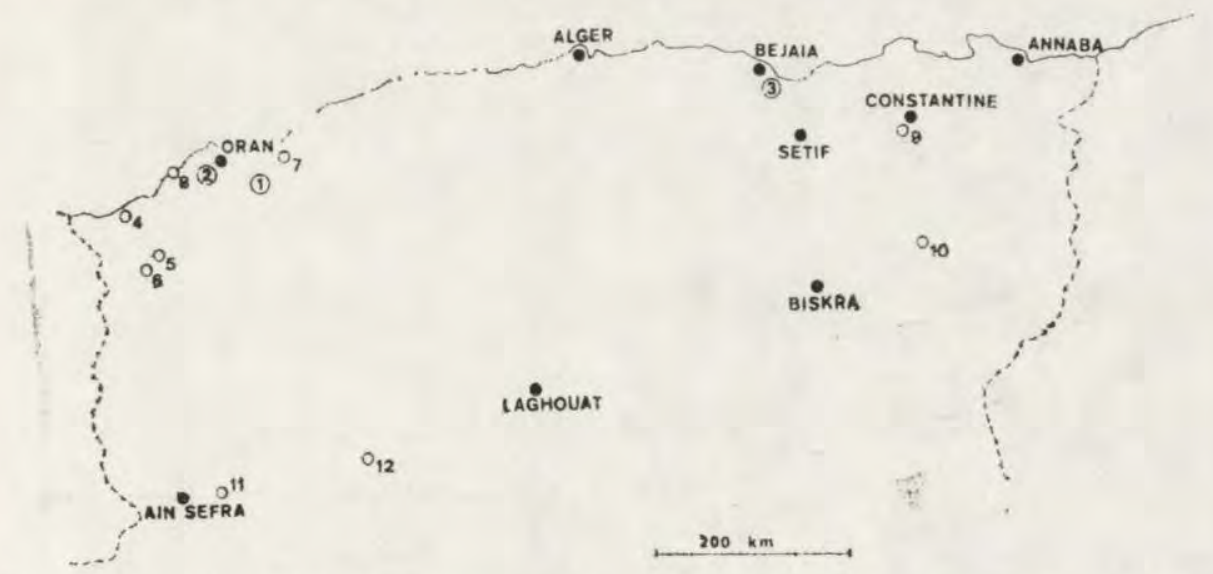

Fig. 1. Situation of bat shelters investigated in northern Algeria, $1-\mathrm{Sig}, 2-$ Misserghin, 3 - Aokas, 4 - Honaine, 4 - Yebdar, 6 - Sebdou, 7 - Ain Nouissy, 8 - Madakh, 9 - Tiddis, 10 - Mt.Chelia, 11 - Ain Ouarka, 12 - Brezina.

that period the outside temperature by the entrance ranged from $5^{\circ} \mathrm{C}$ (December-January) to $20^{\circ} \mathrm{C}(\mathrm{March})$ and in the lowest part of complex A from $7.5^{\circ} \mathrm{C}$ in January to $14^{\circ} \mathrm{C}$ in March. In the terminal parts of complex $\mathrm{B}$ the temperature fluctuated slightly, between 16 and $17^{\circ} \mathrm{C}$. The relative humidity measured using an Assman psychrometer was $65-80 \%$ on the outside and $70-90 \%$ in deep parts of both complexes of galleries.

The total number of bats at Sig underwent marked fluctuations, ranging from 45 to more than 1300 , over a space of the year, and being the greatest in winter months (Fig. 2). Two of the 7 species were present sporadically: $R$. hipposideros once, and $R$. blasii eight times in spring and autumn and only once in winter. In the winter season 


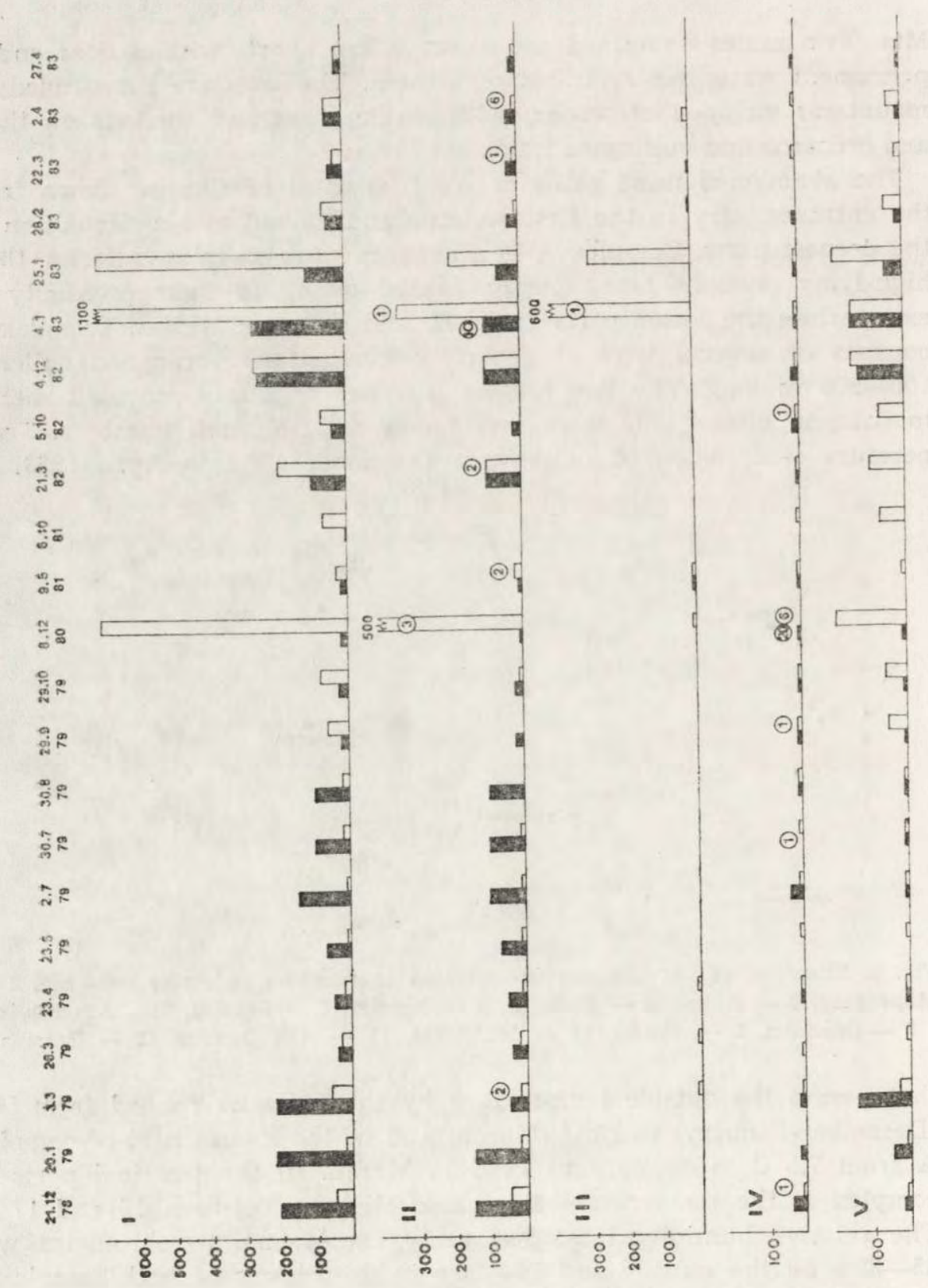

Fig. 2. Dynamics of the bat population at Sig. Visits during which not all galleries were explored have not been taken into account. The filled rectangles represent the number of specimens in complex A, the open rectangles that in complex $\mathrm{B}$. I - Total number of bats; II - Rhinolophus ferrumequinum, in circles the number of specimens of $R$. blasii; III $-R$. mehelyi, in cirles the number of specimens of $R$. hipposideros; IV - Myotis blythi, in circles the number of specimens of M. emarginatus; V - Miniopterus schreibersi. 
R. ferrumequinum (up to 500 specimens), $M$. schreibersi (up to 300 ) and $M$. blythi (up to 40 ) were encountered regularly, while $M$. emarginatus was much less common. In the warm season the bats of these species were few in number, and only two of them, $R$. ferrumequinum and $M$. emarginatus, formed small maternity colonies at Sig. In the years 1978-1982 $R$. mehelyi was found irregularly at Sig, only $1-5$ specimens in the winter. At the beginning of January 1983, a group of at least 600 of these bats appeared; towards the end of January they were already less numerous and in following months only a few specimens remained.

\subsection{Misserghin}

The cave known as "La 4ème source de Misserghin" (Larat, 1964) is situated at about $300 \mathrm{~m}$ a.s.l. on the slope of the hills of Mourdjadjo, $6 \mathrm{~km} \mathrm{~S}$ from the village of Misserghin near Oran $\left(35^{\circ} 38^{\prime} \mathrm{N}, 0^{\circ} 43^{\prime} \mathrm{W}\right)$. It is surrounded by woods in a fairly good state of preservation; farther away the slopes are covered by maquis. This site is partly artificial, for it begins with a narrow gallery, about $80 \mathrm{~m}$ long with a small stream trickling in its bottom. At its end a side gallery leads to two natural rock-chambers with short ramifications. The entrance gallery extends for about $1 \mathrm{~km}$ beyond these chambers and reaches another opening. This last part was not visited when the cave was inspected for the numbers of bats. The galleries were made at the end of the 19th century for water intake, although it is possible that the natural chambers previously had been accessible to bats. The considerable age of their colonies is evidenced by a big accumulation of guano.

Temperature was measured only from November 1982 to March 1983. In that period it was almost stable in the chambers, ranging between 21 and $23^{\circ} \mathrm{C}$; no doubt the temperature is higher in the summer. The relative humidity was $95-100 \%$. In the entrance gallery the temperature was low and more variable, about $17^{\circ} \mathrm{C}$, and the humidity was about $90 \%$.

Bats were consistently present at Misserghin and were more numerous in the summer (up to 1000 specimens), than in the winter (Fig. 3).

Out of the 6 species encountered, $R$. hipposideros appeared only twice at the very entrance in the winter, while $R$. blasii was observed twice in the entrance gallery. $R$. ferrumequinum was encountered more frequently and exclusively in the entrance gallery, its numbers being larger in the winter. The remaining 3 species formed a common maternity colony in the warm chambers. They were most numerous in the spring and summer. Smaller numbers stayed in the chambers and 


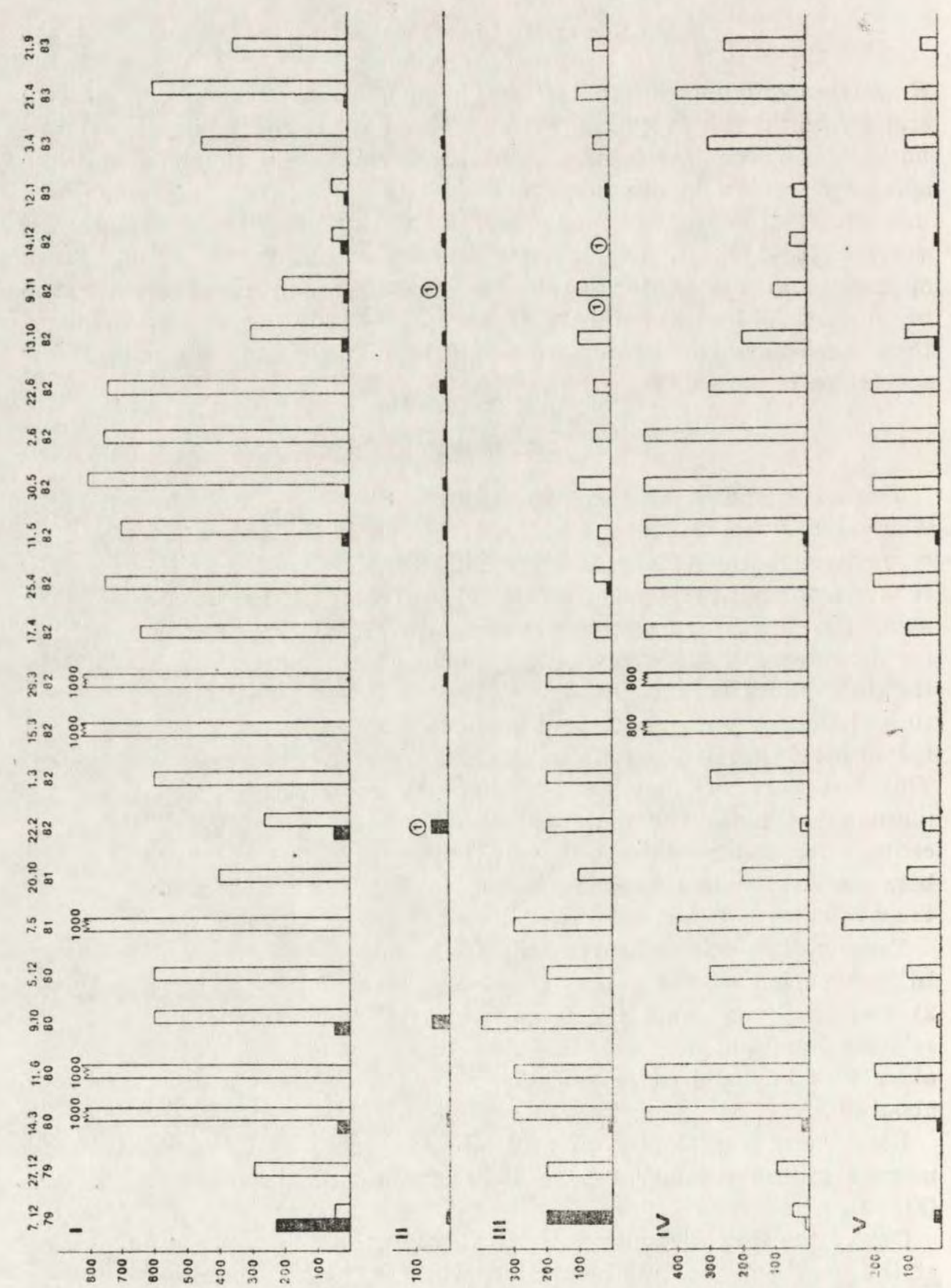

Fig. 3. Dynamics of the bat population at Misserghin. Visits during which the cave chambers were not explored have not been taken into account. The filled rectangles represent the number of specimens in the entrance gallery, the open triangles - in chambers. I - Total number of bats; II - Rhinolophus ferrumequinum, in circles the number of specimens of $R$. blasii; III $-R$. mehelyi, in circles the number of specimens of R. hipposideros; IV - Myotis blythi; V Miniopterus schreibersi. 
sometimes in the entrance passage in the autumn and winter. $M$. blythi was most numerous, $M$. schreibersi being less numerous. $R$. mehelyi was fairly numerous year-round, but mainly in the reproductive season. A decline in the number of $M$. mehelyi between 1981 and 1983 was noted.

On 11 May 1982, during a period of exceptionally cool and rainy weather, a cluster of hypothermal bats was found in the entrance gallery. Among them were female $M$. blythi and $M$. schreibersi with sucklings, and $R$. ferrumequinum. At the same time other bats stayed in the warm cave chambers and were active.

\subsection{Aokas}

The cave near the village of Aokas $\left(36^{\circ} 38^{\prime} \mathrm{N}, 5^{\circ} 14^{\prime} \mathrm{E}\right)$ mentioned as "Grotte Féerique" in literature, has been known as a quarter of bats for more than 100 years (Lataste, 1885). Its opening is situated close to the sea, slightly above its level. The cave consists of a large entrance chamber and two galleries starting at its end and in part widened by man. The bats stayed only in the terminal galleries, in which the temperature was $17-23^{\circ} \mathrm{C}$ in the winter and $20-26^{\circ} \mathrm{C}$ in the summer; the humidity was high. The cave is surrounded by mountain slopes grown over by garigue.

The number of bats at Aokas was much larger in warm seasons than in winter (Fig. 4). Eight species were identified, of which M. nattereri was observed only once. From 1 to $12 \mathrm{M}$. capaccinii were present mostly during winter, and $M$. emarginatus was seen twice, in spring. The horseshoe bats (Rhinolophidae) were represented by 3 species $R$. ferrumequinum, present in small numbers in winter, more numerous only at the beginning and the end of the 1982/1983 winter; $R$. euryale, numerous in autumn and spring; and $R$. blasii, which was observed chiefly in the winter but was also fairly abundant in May, 1982. None of the horseshoe bat species chose the cave as its breeding place.

M. blythi and M. schreibersi constituted the bulk of the bat population. Both had their maternity colony in the cave. M. schreibersi either formed small monospecific colonies or its females with youngs joined the groups of $M$. blythi. Both species were few in number, if present at all, in the winter. Pregnant females of $M$. emarginatus were also observed.

About 10 active and flying bats were present in the cave on the evening of 27 January 1983. None was caught in the net set in the entrance chamber, which suggests that they did not fly outside. 


\subsection{Other caves}

Western Algeria. Mersa Agla Cave at Honaine $\left(35^{\circ} 10^{\prime} \mathrm{N}, 1^{\circ} 39^{\prime} \mathrm{W}\right)$ lies in a rocky wall rising directly above the sea. It is a spacious maze of chambers and galleries, more than $1 \mathrm{~km}$ long (Larat, 1964), and

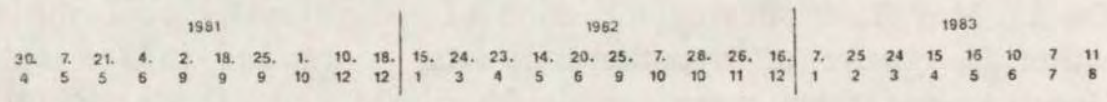
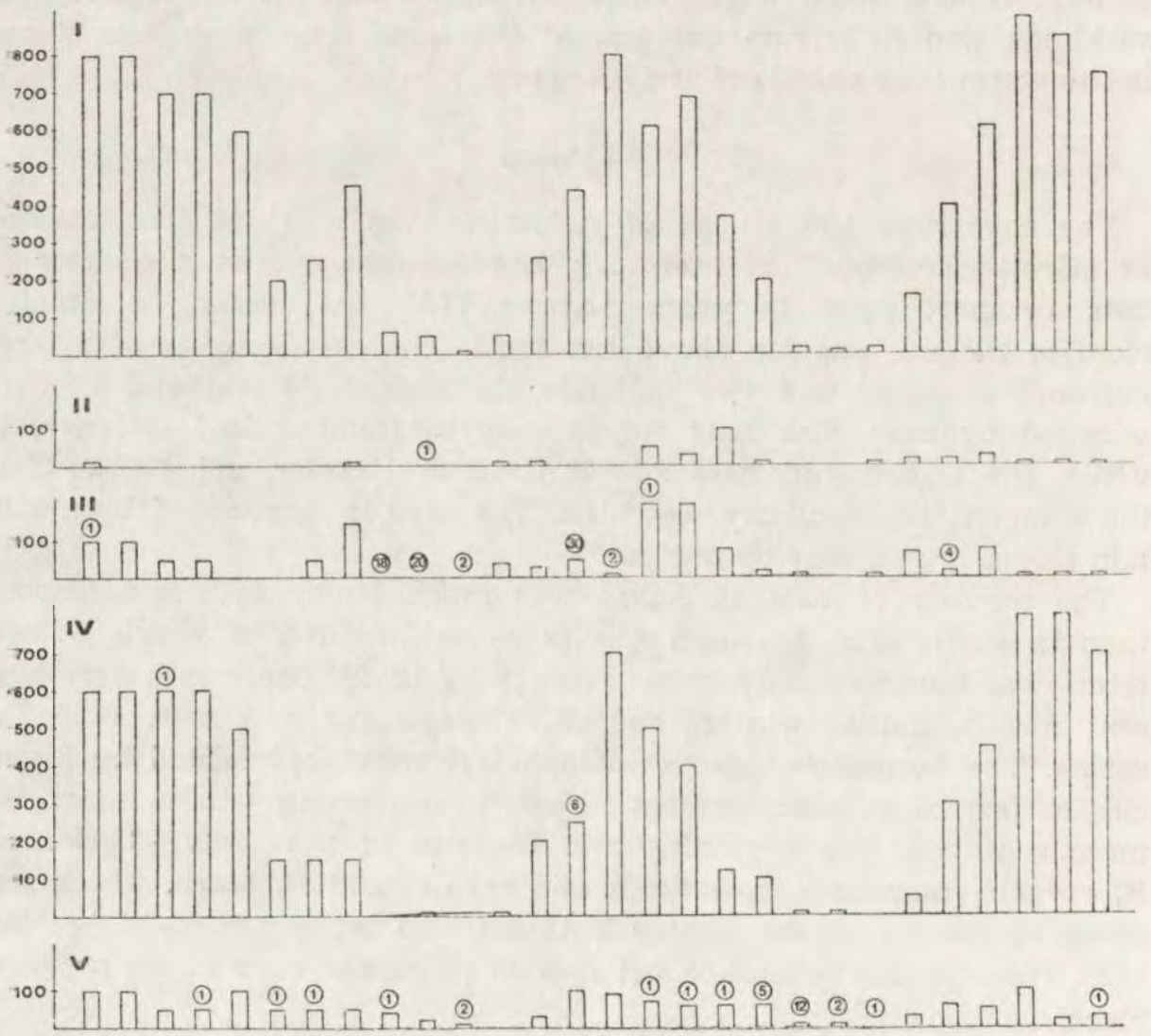

Fig. 4. Dynamics of the bat population at Aokas. I - Total numer of bats; II Rhinolophus ferrumequinum, the numbers in circles refer to Myotis nattereri; III $-R$. euryale, the number in circles refer to $R$. blasii; IV $-M$. blythi, the numbers in circles refer to $M$. emarginatus; V - Miniopterus schreibersi, the number in circles refer to $M$. capaccinii.

rather damp. It was visited 7 times in 1979-1983. Every spring a large maternity colony of bats occupied one of the chambers, inaccessible for direct observation but numbering at least 1000 specimens. They were mainly $M$. blythi, but also $M$. schreibersi and probably $R$. mehelyi. 
In cool periods there were no bats in that chamber. Single specimens of $M$. blythi, $M$. schreibersi and $R$. mehelyi were encountered in the entrance chambers in summer and from several to about $100 \mathrm{M}$. blythi were present in autumn.

"Grotte de Yebdar" is situated near Ain Fezza in the Tlemcen Mts. $\left(34^{\circ} 53^{\prime} \mathrm{N}, 1^{\circ} 18^{\prime} \mathrm{W}\right)$. It is a $280 \mathrm{~m}$ long chamber sloping down from the entrance (Larat, 1964). Eleven hibernating specimens of $R$. ferrumequinum were found there on 22 November 1979. "Aven de Yebdar" is several hundred metres away from the previous cave. It is a vertical pit, which at a depth of $50 \mathrm{~m}$ expands to form a large, damp and cool chamber. A maternity colony of $M$. nattereri and 3 bats of the species $R$. euryale and one of $M$. schreibersi were found in it on 14 April 1983.

In the same mountains near Sebdou there is a cave $\left(34^{\circ} 41^{\prime} \mathrm{N}, 1^{\circ} 19^{\prime} \mathrm{W}\right)$, which is the source of the Tafna River. The cave is several kilometres long (Larat, 1964) and, except for a few chambers, its bottom is flooded. The presence of maternity colonies of $M$. blythi and $M$. schreibersi in this cave has been documented (Rotrou, 1939). A colony of about 700 females of $M$. blythi with sucklings was observed in it on 14 June 1979.

Ain Nouissy Cave near Mostaganem $\left(35^{\circ} 48^{\prime} \mathrm{N}, 0^{\circ} 2^{\prime} \mathrm{E}\right)$ begins with a vertical pit, at the bottom of which there is a system of galleries, partly filled with water. In 1979 and 1983 small numbers of $R$. ferrumequinum and $M$. blythi stayed there in spring. The same species were found in Bou Yacor Cave near Misserghin (Larat, 1964) also in spring.

In the rocky sea-shore at Madakh $\left(35^{\circ} 40^{\prime} \mathrm{N}, 1^{\circ} 0^{\prime} \mathrm{W}\right)$ there are several small caves, in part filled with sea-water and well lighted. On 1 July 1983 a maternity colony of $M$. ferrumequinum and $M$. emarginatus was present in one of them. On 16 September 1983 there were no bats in this cave, while in the neighbouring one about 50 female $R$. ferrumequinum were observed.

Eastern Algeria. There are a number of caves on the sea-shore in the proximity of the above-described cave at Aokas. Single specimens of $R$. hipposideros and $R$. ferrumequinum were found in the cave at Tichi in September 1981. Thirty $M$. blythi and a colony of about 100 $R$. euryale stayed in a somewhat larger cave near Souk el Tenine at that time. At the time of our visits to this cave in winter and spring small numbers of $M$. schreibersi, $R$. euryale, $R$. blasii and $R$. ferrumequinum were present. The caves situated farther to the east, near Les Falaises and Aftis gave shelter to single specimens of $R$. ferrumequinum, and the "Grotte de la Madelaine" to those of M. blythi.

In the same region but farther inland, in the Chabet-el-Akra Valley 
$\left(36^{\circ} 39^{\prime} \mathrm{N}, 5^{\circ} 17^{\prime} \mathrm{E}\right)$, there are several man-made, $50-800 \mathrm{~m}$ long galleries hewn in the rocks. The winter temperature in them ranged from $12-18^{\circ} \mathrm{C}$. Single specimens of $R$. hipposideros, $R$. euryale, $R$. blasii and $R$. ferrumequinum were found there in winter and spring.

A maternity colony of $R$. ferrumequinum was observed in a small cave at the foot of Chelia Mt. in the Aures Mts. $\left(35^{\circ} 19^{\prime} \mathrm{N}, 6^{\circ} 40^{\prime} \mathrm{E}\right)$ on 17 July 1979.

A small, very warm cave ("Grotte Chaude") lies at Tiddis near Constantine $\left(36^{\circ} 22^{\prime} \mathrm{N}, 6^{\circ} 39^{\prime} \mathrm{E}\right)$. On 9 May 1980 it contained a big colony of $M$. blythi and on 20 November 1981 about 200 bats were present in 3 groups, of which only one was accessible and consisted of $R$. mehelyi, $M$. blythi and M. schreibersi.

The Saharan Atlas range is the southern boundary of the occurrence of the Meditterranean species of bats, which are accompanied by desert elements here. El Rhar Cave at Ain Ouarka $\left(32^{\circ} 44^{\prime} \mathrm{N}, 0^{\circ} 10^{\prime} \mathrm{W}\right)$ is situated in a semidesert and rocky region. It consists of a single gallery, about $800 \mathrm{~m}$ long (Collignon, 1982), very dry in its first segment, damp and containing a water body in the deep part, which was not visited. About 25 males and females of $R$. mehelyi formed several groupings in the first segment of the cave on 8 January 1981. On 20 May 1982 19 specimens of Asellia tridens (Geoffroy, 1913), were mist netted at the entrance as they exited. On 2 November 1982 there were about $10 R$. mehelyi in the first segment of the cave, and on 17 July 1983 a male $R$. blasii was caught in a net at the entrance.

There are several caves at Brezina $\left(33^{\circ} 6^{\prime} \mathrm{N}, 1^{\circ} 16^{\prime} \mathrm{E}\right)$ on the boundary between the desert and unwooded rocks. In one of them 2 female Plecotus austriacus (Fischer, 1829) were found on 12 February 1981 and in the others single specimens of $R$. mehelyi. On 30 October 1981 one $P$. austriacus and one $R$. hipposideros stayed in them.

\section{ANNUAL LIFE CYCLE OF PARTICULAR SPECIES}

\subsection{Rhinolophus ferrumequinum (Schreber, 1774)}

Caves serve as the hibernating quarters and breeding places of this species. In autumn torpid males and females were present as either single isolated individuals or in groups. When clustered, specimens did not touch each other but hung loosely, wrapped in their wing-membranes. Their number fluctuated considerably, which indicates frequent translocations between roosts. Juveniles perhaps stayed separately from adults. For example 25 September 1982 there were only juveniles at Aokas, where they formed an admixture with the colony of $R$. euryale. 
During the coolest winter months this species clearly prefered rather cool roosts. At Misserghin specimens were never observed in warm chambers, only in the cool entrance gallery. At that time only infrequent lone males were found at Aokas. This species was more abundant in cooler galleries at Sig. There we found both single males and females and mixed sex aggregations, sometimes with a central cluster of $M$. schreibersi or mixed with $R$. mehelyi.

In spring and summer torpid males, single or in associations, were encountered in caves; subadult females, not participating in reproduction, appeared in them exceptionally. At Sig a fairly large association of males (about 50) was also observed in a mixed colony of male $M$. schreibersi and female $M$. emarginatus; these last with sucklings.

In spring and early summer females formed maternity colonies near the openings of caves. Specimens of other species also occured in these colonies: $M$. schreibersi at Sig and $M$. emarginatus at Madakh.

Parturition occured in June. The females at Sig had already delivered their young on 2 July 1979; on 30 August the young were volant, although they differed distinctly from the adults. On 16 September 1983 the females were still in lactation at Madakh.

\subsection{Rhinolophus blasii Peters, 1866}

This species was rarely encountered in the caves of Western Algeria. At Sig single specimens, both males and females, always active, were seen in the warmest parts of the galleries in the cool season. At Aokas it appeared in larger numbers with males prevailing, especially at the beginning and towards the end of the cool season. On 14 May 1982 some specimens of $R$. blasii were present in a mixed colony, which included $M$. emarginatus, $M$. schreibersi and $R$. euryale. Some of these were active and other torpid. No data concerning the reproduction of this species were obtained.

\subsection{Rhinolophus euryale Blasius,, 1853}

In western Algeria, where this species seems to be rare, only two young females were found in the Aven of Yebdar on 13 April 1983. At Aokas $R$. euryale appeared in a fairly large numbers in spring and autumn. Both sexes were present either singly (torpid) or in associations (active). On 14 May 1982 bats of this species were found in mixed colonies, which also included $M$. blythi or $R$. blasii, M. emarginatus and $M$. schreibersi. At mid-winter there were no specimens of $R$. euryale at Aokas but in summer males appeared sporadically. No data concerning reproduction were obtained. 


\subsection{Rhinolophus hipposideros (Bechstein, 1800)}

In the cool season single bats of this species, almost always males, were sporadically seen in the coolest places, usually close to the opening. The only female found at Sig on 21 January 1983 had a vaginal plug.

\subsection{Rhinolophus mehelyi Matschie, 1901}

Although observed only irregularly, this species was present in caves year-round. In the autumn it was sometimes missing and at the time of other visits numerous at Misserghin (Fig. 3). Then it was encountered in the warm chambers of the cave, where very fat females and males void of fat formed a common colony. At that time at Sig there were only single specimens of both sexes and they were active.

In the winter these bats were usually numerous at Misserghin, staying either in the entrance gallery or in warm chambers and forming monospecific associations or mixed colonies with $M$. blythi and $M$, schreibersi. At Sig this species was not aboundant in winter, single active specimens being found alone or in association with $R$. ferrumequinum. It was numerous at Sig only in the winter of 1983, when it formed contact clusters with groups of $M$. schreibersi in the centre. Torpid specimens alone and in dense clusters were also observed at Brezina and Ain Ouarka.

From 4-20 bats, males and females, were present at Sig in the spring, but reproduction was not observed there.

A breeding colony stayed at Misserghin in the spring and summer. It formed an interspecific association, together with $M$. blythi and $M$. schreibersi; however the horseshoe bats maintained separate groups within the colony. At first both males and females were present, but only females remained at the time of parturition.

In 1982 pregnant females were observed in Misserghin from 29 March to 2 June. On 30 May a parturient female was seen and at the same time there were already some haired young. On 2 June most females had sucklings; on 22 June one of the females was carrying a suckling, while other young, some of them being volant, formed a separate association on the wall. These observations indicate a range of parturition dates extended from May to the beginning of June.

A histological examination of testes of 11 specimens showed that on 15 March 1982 adult males from Misserghin were still sexually inactive. At that time seminal line was represented by few spermatogonies present near the basal pellicle (P1.I/1). The lumen of the seminiferous tubules was considerable (ca. $70 \mu$ ), but there were no spermatozoa in them. On 11 May order I spermatocytes were visible beside the sper- 
matogonies in an adult male. The diameter of its seminiferous tubules has increased to $85 \mu(\mathrm{Pl} . \mathrm{I} / 2)$, and the epididymis of the adult males. was filled with spermatozoids (Pl. I/3). At the same time the diameter of the seminiferous tubules in a subadult male was $55 \mu-$ this specimen, in the second year of life, apparently had not attained full sexual maturity.

On 11 May a corpus luteum, as well as some primary and atresial follicles were visible in the ovary of a pregnant female (Pl. VII/4). On 17 April a subadult female showed a juvenile aspect of the ovary with numerous primary and only two secondary follicles, which indicated that in the second year of life it had not become sexually mature. The pregnant females dissected $(n=9)$ had always one foetus each.

Unlike other horseshoe bats, $R$. mehelyi forms contact clusters, in. which specimens touch each other. Outside the periods of parturition and lactation clusters consist of males and females. Bats of other species are often mixed with them. In the cool season $R$. mehelyi were more rarely in the state of torpidity than were the members of other species.

\subsection{Myotis blythi (Tomes, 1857)}

This was the most numerous species in the caves of northern Algeria, being encountered in them all the year round.

Mating groups were usually present in the cave at Aokas from August to October. They consisted of a male and a female hanging together, the male touching the female with the ventral side of body and sometimes embracing it with the wings. These couples were accompanied by less numerous males with harems of $2-4$ females (Table 1).

Table 1

Number of mating groups of Myotis blythi in Aokas.

\begin{tabular}{lrrrrr}
\hline & \multicolumn{5}{c}{ No. of specimen in group } \\
Date & 2 & 3 & 4 & 5 \\
\hline 2 Sept. 1981 & 138 & 18 & 5 & 1 \\
7 Oct. 1982 & 85 & 5 & 1 & -1 \\
11 Aug. 1983 & 42 & 13 & 2 & 1 \\
\hline
\end{tabular}

Juveniles were also present either as lone individuals or aggregations. On 7 October 19823 males were seen with their penes erected.

At Sig $M$. blythi was not numerous at late summer and autumn but most specimens formed mixed sex pairs. On 28 October 1979, some females were found with perigenital hair stuck together with sperm. No associations of juveniles were observed. 
At Misserghin couples and groups of 3 specimens (one consisted of 2 males and a female) and also separate males were found in the autumn. On 9 November 1982 there were still several pairs; however, separate specimens, both males and females, were far more numerous.

A female born not long before and banded at Aokas on 20 June 1982, was found as a partner in a mating couple in this cave on 25 September that year. This suggests that females can mate in year of their birth.

None of the caves visited served as hibernacula for large aggregations of $M$. blythi. At Aokas a colony of about 50 specimens, with small numbers of $M$. capaccinii and $M$. schreibersi, was observed at the latest on 26 November 1982. During the winter there were either no $M$. blythi present or only a few torpid specimens, solitary or in twos (often of the same sex).

At Sig, Misserghin and in other caves M. blythi occurred in small numbers in the winter. They were both juveniles and adults, single and in small clusters $(2-5)$. During the winter members of this species were never seen in mixed species associations.

The reproductive organs of 14 males were examined histologically in the winter and spring. Adult and juvenile specimens differed distinctly. In November the seminiferous tabules of adults still contained spermatozoa and the epididymis was filled with them. From December onwards the diameter of the seminiferous tubules was smaller, and they did not contain any spermatozoa. The resting period of the testes lasts until February. By 7 March 1983 spermatogenesis had begun as evidenced by presence of spermatocytes of order I. On 11 May 1982 the testes already produced spermatozoa and the epididymis was at the same time filled with the spermatozoa, probably of the previous year.

Juvenile males did not contain spermatozoa in the epididymis in the winter and spring. An increase in the diameter of the seminiferous tubules was visible on 26 March 1983, and in June spermatogenesis had commenced, but the epididymis was still empty.

At Misserghin the formation of breeding colonies began earlier than at Aokas. On 22 February 1982, there were only a few isolated specimens at Misserghin, but by 1 March 1982 , the colony was already numerous (Fig. 3). The parturition period extended for more than a month. On 17 April 1982, three young were observed on the wall of the cave, and most of the females were pregnant. On 11 May 1982, some young had acquiered hair, but still one pregnant female was collected. At the same time the offspring of all the species making up the colony ( $M$. blythi, M. schreibersi and $R$. mehelyi) were segregated 
in separate colonies on the roof of the cave. These associations still existed on 2 June 1982, but as early as 22 June, the young differed little from the adults, though the females kept on lactating. The dissected pregnant females $(n=5)$ had one foetus each.

The breeding colonies at Aokas formed later. In successive years they were observed at the earliest on 30 April in 1981, 23 April in 1982 and $29 \mathrm{March}$ in 1983 . They contained an admixture of $M$. schreibersi. Adult females predominated in the associations, but nulliparous females and males were also present. In 1981 the first young (about 1 week old) was observed on 21 May. In 1982 first young were collected on 14 May, most females being still pregnant at that time. No pregnant females were found on 20 June 1982. In 1983 the first young were observed on 16 May (10\% of the females nursed sucklings; the others were pregnant). On 10 June 1983 all the females carried young, aged $1-3$ weeks, and by 7 July all the young were volant.

\subsection{Myotis nattereri (Kuhl, 1818)}

In the aven of Yebdar about 300 specimens, gathered in a dense cluster at the roof, were observed on 13 April 1983. A sample taken contained 14 males with small testes and 8 females, each with one small foetus in the right uterine horn. A female of this species was also found at Aokas in winter.

\subsection{Myotis capaccinii (Bonaparte, 1837)}

As regards caves, this species was found only in Aokas, where it stayed singly in different seasons, somewhat more numerously in the winter (up to 12 specimens). One was encountered in a colony of $M$. blythi. Males predominated, and only one juvenile female was observed.

On 1 May 1982 a female bearing an embryo was caught in a net near Sebdou in western Algeria. A lactating female was netted near Tebbar on 2 June 1983. These observations indicate that the parturition season of this species falls in May.

\subsection{Myotis emarginatus (Geoffroy, 1806)}

In winter M. emarginatus was found only at Sig, where single torpid specimens, males and females, were present. Here a colony of $R$. ferrumequinum and male $M$. schreibersi was found on 2 July 1979; among them were lactating females of $M$. emarginatus and one subadult male of this species. Several females and young formed an adjacent group and a young $M$. emarginatus, already volant, was found nearby. On 9 May 1981 a colony of about 20 specimens was present at the roof 
near the entrance. Five of them were caught, all non-pregnant females.

A colony of $M$. ferrumequinum, which included groups of $M$. emarginatus (one suckling was caught) was found in a sea cave near Madagh. On 10 June 1982, a female bearing a nearly full-term foetus was caught in a net in the proximity of this cave.

In Aokas on 14 May 1982, pregnant females of M. emarginatus were present in the colony of $R$. euryale, $R$. blasii and $M$. schreibersi.

Maternity colonies of $M$. emarginatus therefore occur in associations of other species, notably those of horseshoe bats. Parturition takes place probably in the first half of June.

\subsection{Miniopterus schreibersi (Kuhl, 1819)}

These bats were numerous in caves throughout the year. In the autumn torpid individuals were observed as solitary individuals, in pairs (usually a male and a female), in small contact clusters, and also in the colonies of $M$. blythi.

Small numbers, chiefly males, occupied underground shelters in winter. Single specimens or clusters of $2-5$ were found at Aokas. At Misserghin this species was not numerous either, usually found only in the cool entrance gallery. At Sig $M$. schreibersi was more abundant in winter. In addition to single specimens and small groups, their clusters occurred amidst the colonies of $R$. ferrumequinum and $R$. mehelyi.

At Sig, where $M$. schreibersi did not form maternity associations, its number decreased starting from April. Only lone torpid males or active ones in the associations of $R$. ferrumequinum and $R$. mehelyi were present there.

In spring and summer $M$. schreibersi formed a common maternity association with $M$. blythi and $R$. mehelyi at Misserghin. In 1982 females with sucklings were observed on 25 April; on 30 May some females nursed sucklings, while most young ones were in dense clusters at the roof outside the colony of the adults. They were surrounded by more loosely gathered young of other species. The young of $M$. schreibersi in the clusters appeared to be the same age. On 2 June the clusters still persisted, and on 26 June the young bats, already volant, were together with the adults in a mixed association.

On 30 April and 7 May 1981 M. schreibersi was numerous at Aokas; torpid specimens hung singly and active occurred in the colony of $M$. blythi. On 21 May pregnant females were noted, whereas on 20 June 1982 , the colony contained males as well as pregnant and lactating females.

Parturition lasts from mid-April almost to the end of June and seems to take place earlier in western Algeria than in the Aokas region. 


\section{DISCUSSION}

The foregoing observations indicate that the bats found in the caves of northern Algeria stay in that territory throughout the year and are not, as Heim de Balsac (1936, p. 43) supposed, winter migrants from Europe.

Weber (1912) considered the question whether the bats of Algeria hibernate. Here he found some specimens belonging to several species in the state of torpor in the winter season and on this basis claimed that they were hibernating. His observations, like those presented in this paper, were made during the daylight hours and therefore do not allow an unequivocal answer to the question posed, in as much as hypothermous bats were present in caves during the day in the season of their active life.

When the weather is favourable, flying bats are observed in northern Algeria in the winter (Gaisler, 1984). The data refer chiefly to the places where Pipistrellus kuhli (Kuhl, 1819) forages in that season. This agrees with the observations of year-round activity in this species in the Near East (Atallah, 1977). Previously there was no information from Algeria concerning winter activity in cave-dwelling bats. The observations made at Aokas indicate that their flying activity in winter is limited to the insides of the caves.

The caves of Algeria, especially the warmer ones, contained more bats in summer than in winter. The same has also been found in other Mediterranean areas, e.g. in Dalmatia (Dulić, 1961), Provence (König, 1961), Sardinia (Frick \& Felten, 1952) and Corsica (Kahman \& Goerner, 1956). This distinguishes them from the caves of Central Europe, which serve principally as winter quarters of bats, whereas maternity colonies are encountered exceptionally in them in summer. Dulić (1961) found in Dalmatia that bats are numerous in caves at the beginning and at the end of the winter, but they disappear from them in the coolest period (December-February). It may be supposed that at that time they seek out hibernacula of lower temperatures. This may be necessary both for the lowering of metabolism in the period of food shortage and for the prevention of ovulation and survival of sperm deposited in the reproductive tracts of females in autumn. In the coolest winter months a small number of bats were found in Algerian caves; they were somewhat more numerous in the abandoned mine at Sig, where the temperatures were the lowest. These were however mostly males.

No places of mass hibernacula, especially of females, of the common species $M$. blythi and $M$. schreibersi have been discovered. Since mi- 
grations over the Mediterranean Sea to cooler regions are hardly probable, it should be supposed that they winter in underground roosts characterized by lower temperatures but so far unexplored, or that they move to the mountainous regions of Algeria (e.g. Djurdjura Mts.).

The hibernation period in northern Algeria is shorter than in the European portions of the ranges of species examined. In March in the cave at Misserghin fresh excrement began to accumulate under the colony of bats, which proves that they had started foraging regularly. Movements of bats within and between hibernacula appeared to occur especially often in Algeria. This was indicated by changes in the composition, number and distribution of bats at consecutive visits to the caves of Algeria. Such movements between hibernacula also have been documented in Europe (Daan, 1973).

Also in spring, when the bats were already fully active, they sought particularly cool places during unfavourable weather conditions, which limit the possibilities of foraging. At such times, bats became hypothermic, even in the period of raising the young (p. 200). Ransome (1;73) found a similar phenomenon in $R$. ferrumequinum in Europe.

Despite the lack of detailed measurements we believe that different species prefer different temperatures in the winter season. $R$. hipposideros was found exclusively in the coolest parts of the caves, $R$. ferrumequinum also preferred cool places, although torpid specimens were sometimes encountered at temperatures up to $21^{\circ} \mathrm{C}$ in spring. $R$. blasii and $R$. mehelyi showed a preference for the highest temperatures in their shelters and often were immediately able to fly, even in winter, which is confirmed by Dulić's $(1961,1963)$ observations from Yugoslavia.

According to the observations by McNab (1974) bat species of larger body size choose the coolest places for hibernation. Our observations indicate species specific thermopreferences which are related to geographical distribution and not to the size. $R$. hipposideros, the smallest of the horseshoe bats, prefers the lowest temperatures in Algeria, and in Europe extends furthest to the north. $R$. ferrumequinum, the largest, has a more limited range to the north, and $R$. blasii and $R$. mehelyi, of medium size, which choose the highest temperatures, have their ranges limited to the Mediterranean Region.

Despite their shorter and interrupted hibernation, all the species observed, with the exception of $M$. schreibersi, have the typical annual cycle of temperate bats, that is, a break between insemination and fertilization. The parturition season differs among species, and even within the same species there may be considerable range in the dates of parturition. It was at least a month in $M$. blythi at Misserghin. This 
species also showed great regional differences. In the same year parturition occurred from the middle to the end of May at Aokas and from mid-April to mid-May at Misserghin. There are few data concerning this species from other regions of North Africa. Hanak \& Elgadi (1984) noted a case of parturition in Libia on 9 April and Baker et al. (1974) found two embryos in a female in October. This last observation shows that in exceptional cases fertilization may take place before the hibernation season.

A comparison of the annual cycle, notably reproduction, of the Algerian species with populations from other regions is difficult, because the beginning of August (Saint Girons et al., 1969; Ransome, 1983), in Algeria it occurs in June.

As regards $R$. ferrumequinum, in France and England parturition extends from the end of June to the end of July, exceptionally over the beginning of August (Saint Girons et al., 1969; Ransome, 1983), in Algeria in occurs in June.

In $M$. emarginatus parturition takes place between 20 June and 17 July in Spain (Balcells, 1965) and in the first half of June in Algeria.

The very strong tendency to form mixed colonies is characteristic of the cave bats of Algeria. Kuramoto et al. (1969) found that in Japan mixed colonies are frequent in summer, rarer in spring and autumn and do not occur in winter. In the present study they were observed in all the seasons of the year. In the summer the formation of mixed colonies may be of importance to the attainement of a more favourable microclimate by raising the temperature. In the winter the only possible cause seems to be the protection from desiccation.

\section{REFERENCES}

1. Anciaux de Faveaux M., 1976: Distribution des Chiroptères en Algérie avec notes écologiques et parasitologiques. Bull. Soc. Hist. Nat. Afr. Nord, 67: $69-80$.

2. Atallah S. I., 1977: Mammals of the Eastern Mediterranean Region; their ecology, systematics and zoogeographical relationships (I). Säugetierk. Mitt., 25: $241-320$.

3. Baker R. J., Davis B. L., Jordan R. G. \& Binous A., 1974: Karyotypic and morphometric studies on Tunisian mammals: bats. Mammalia, 38: 695-710.

4. Balcells F., 1965: Nuevos datos sobre murcielagos raros en cuevas españolas. Miscel. zool., 2: 149-160.

5. Collignon B., 1983: Etude d'une cavité fossile en milieu aride - El Rhar. Spéléol. en Algérie, 1981-1982: 83-87.

6. Daan S., 1973: Activity during natural hibernation in three species of Vespertilionid bats. Netherl. J. Zool., 23: 1-71.

7. Dulić B., 1961: Contribution à l'étude de la repartition et de l'écologie des 
Cheiroptères dans quelques régions méditerranéennes. Proc. Int. Congr. Zool., 15: $815-816$.

8. Dulić B., 1963: Etude écologique des chauves-souris cavernicoles de la Croatie Occidentale (Yougoslavie). Mammalia, 27: 385-436.

9. Frick H. \& Felten H., 1952: Okologische Beobachtungen an sardischen Fledermäusen. Zool. Jhrb. (Systematik), 81: 174-189.

10. Gaisler J., 1983: Nouvelles données sur les Chiroptères du Nord Algérien. Mammalia, 47: 359-369.

11. Gaisler J., 1984: Bats of Northern Algeria and their winter activity. Myotis, 21-22: 89-95.

12. Hanák V. \& Elgadi A., 1984: On the bat fauna (Chiroptera) of Libya. Věst. Cs. Spol. Zool., 48: 165-184.

13. Heim de Balsac H., 1936: Biogéographie des mammifères et des oiseaux de l'Afrique du Nord. Bull. biol. France Belg., suppl., 21: 1-447.

14. Hill J. E. \& Smith J. D., 1984: Bats - A natural history. Austin, 1-243.

15. Kahman H. \& Goerner P., 1956: Les Chiroptères de Corse. Mammalia, 20: $333-389$.

16. König C. \& König I., 1956: Zur OKkologie und Systematik südfranzösicher Fledermäuse. Bonner, zool. Beitr., 12: 189-228.

17. Kowalski K., 1979: Note on bats from North-West Algeria. African Small Mammal Newsl., 3: 19-21.

18. Kowalski K., 1984: Les chauves-souris cavernicoles de l'Algérie. Spéléol. algérienne, 1982-1983: 43-58.

19. Kunz T. H. (ed.), 1982: Ecology of bats. New York, London, $1-425$.

20. Kuramoto T., Uchida T. A., Nakamura H. \& Shimoizumi J., 1969: Further studies on the dense mixed colony consisting of different species of cave bats. Bull. Akiyoshi-dai Sc. Mus., 6: $47-58$.

21. Larat I., 1964: Inventaire spéléologique du Tell Oranais. Bull. Soc. Hist. Nat. Afr. Nord, 54: 133-184.

22. Lataste F., 1885: Etude de la faune des Vertébrés de Barbarie (Algérie, Tunis et Maroc). I. Catalogue provisoire des Mammifères apélagiques sauvages. Actes Soc. Linn. Bordeaux, 39: 129-289.

23. McNab B. K., 1973: The behavior of temperate cave bats in a subtropical environment. Ecology, 54: 943-958.

24. Ransome R. D., 1973: Factors affecting the timing of births of the Greater horse-shoe bat (Rhinolophus ferrumequinum). Period. biol., 75: 169-175.

25. Rotrou M., 1939: La grotte de la Tafna. Historique - description - faune. Bull. Soc. Hist. Nat. Afr. Nord, 30: 399-408.

26. Saint Girons H., Brosset A. \& Saint Girons M. G., 1969: Contribution à la connaissance du cycle annuel de la chauve-souris Rhinolophus ferrumequinum (Schreber, 1774). Mammalia, 33: 357-470.

27. Weber A., 1912: Observations sur l'hibernation des Cheiroptères en Algérie. Bull. Soc. Hist. Nat. Afr. Nord, 4: 152-153.

Accepted, November 24, 1985. 


\author{
Kazimierz KOWALSKI, Jiři GAISLER, Hassiba BESSAM, Cherifa ISSAAD \\ i Hassen KSANTINI
}

\title{
ROCZNY CYKL ZYCIA NIETOPERZY JASKINIOWYCH W POENOCNEJ ALGIERII
}

\section{Streszczenie}

Jaskinie i inne podziemia północnej Algierii służą za schronienia 10 gatunkom nietoperzy: Rhinolophus ferrumequinum, R. mehelyi, $R$. blasii, $R$. euryale, $R$. hipposideros, Myotis blythi, M. emarginatus, M. capaccinii, M. nattereri i Miniopterus schreibersí. Oprócz ostatniego wszystkie osiągają tu południową granicę zasięgu. Wielokrotne kontrole podziemnych schronień (Ryc. 1) wskazują, że nietoperze przebywają w nich liczniej latem, w okresie rozrodu; zimą są nieco liczniejsze tylko w chłodnych schronieniach (Ryc. 2-4).

Najwięcej danych odnosi się do $R$. mehelyi i $M$. blythi, u których badano także histologię narządów rozrodczych $w$ okresie zimowym i wiosennym. U R. mehelyi jądra zimą są nieczynne i podejmują aktywność dopiero w maju, natomiast zapas plemników w najądrzach zachowuje się do wiosny (Tablica VII). Samce i samice nie biorą udziału w rozrodzie w drugim kalendarzowym roku życia. U $M$. blythi okres spoczynkowy jąder trwa od grudnia do lutego, a osobniki obu płci w drugim roku życia biorą już udział w rozrodzie. U tego gatunku jesienią osobniki dorosłe przebywają parami lub samce tworzą haremy zlożone z 2-4 samic (Tabela 1).

Poród u $M$. b̂lythi ma miejsce od polowy kwietnia do końca maja, u $M$. schreibersi od polowy kwietnia do końca czerwca, u $M$. nattereri i $M$. capaccinii w maju, $M$. emarginatus w pierwszej polowie czerwca, $R$. ferrumequinum w czerwcu, a $R$. mehelyi w maju i początkach czerwca.

Okres hibernacji jest krótszy niż $u$ europejskich populacji tych samych gatunkb́w, a poród przypada wcześniej. Stwierdzono duże różnice indywidualne i regionalne daty porodu.

Nietoperze jaskiniowe w Algierii wykazują wyraźną skłonność do tworzenia wielogatunkowych kolonii mieszanych, przede wszystkim w okresie rozrodu, ale równiez podczas hibernacji. 
EXPLANATION OF PLATE VII.

Rhinolophus euryale, Misserghin. 1 - Male, adult, 13 March 1982, testis, $\times 250$; 2 - Male, adult, 11 May 1982, testis, $\times 250$; 3 - Male, adult, 17 April 1982, epididymis, $\times 500 ; 4$ - Female, adult, 11 May 1982, ovary, X250. 


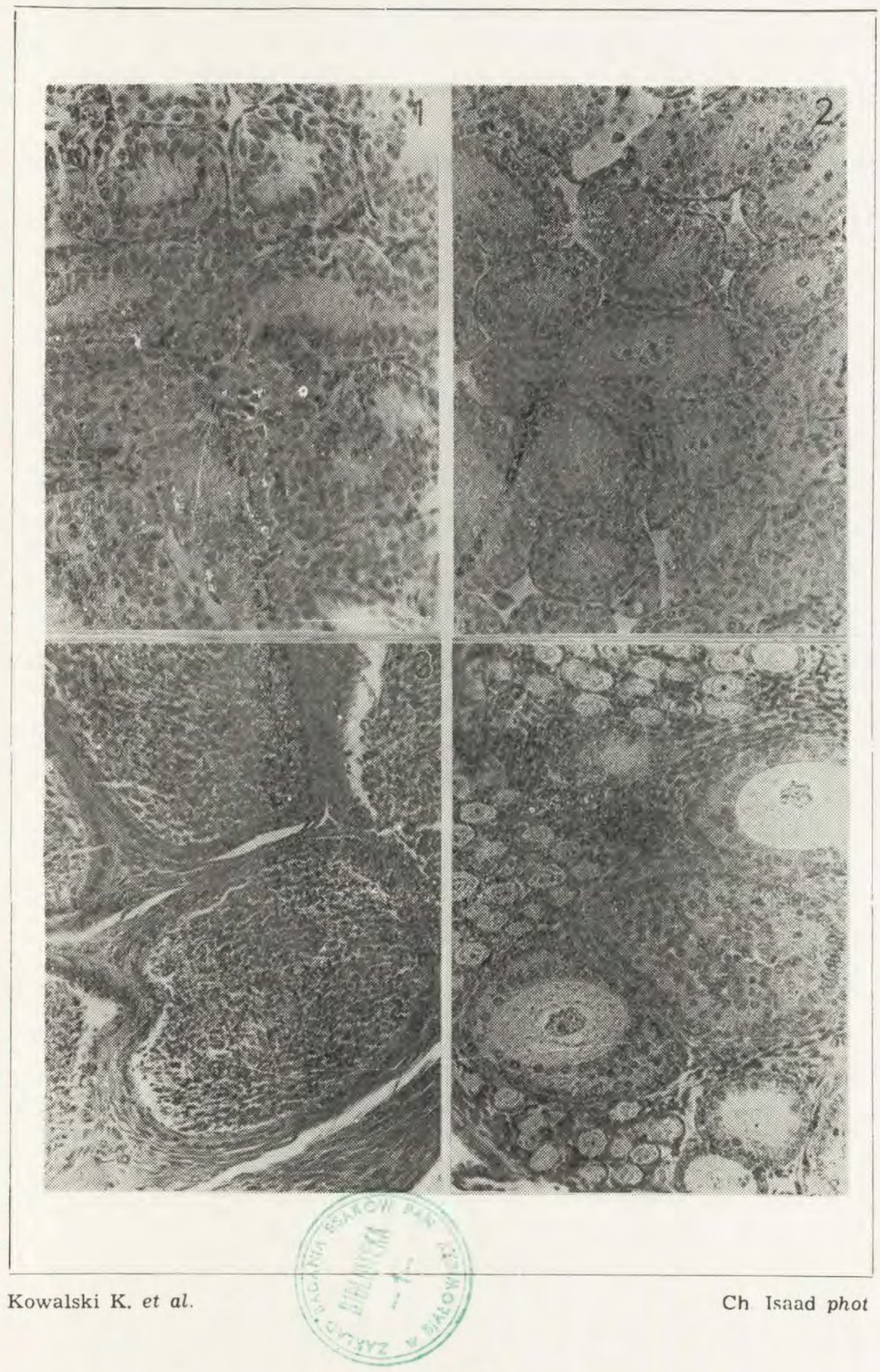

